\title{
Subtilisin QK, a Fibrinolytic Enzyme, Inhibits the Exogenous Nitrite and Hydrogen Peroxide Induced Protein Nitration, inVitro and inVivo
}

\author{
Juho Ko ${ }^{\dagger, * \#, ~ J u n p e n g ~ Y a n ~}{ }^{\dagger, \#}$, Lei Zhu ${ }^{\dagger}$ and Yipeng $\mathbf{Q i}^{\dagger, *}$ \\ National Key Laboratory of Virology, College of Life Sciences, Wuhan University, Wuhan, Hubei, P. R. China 430072 \\ Institute of Microbiology, College of Life Sciences, KIM IL SUNG University, Daesung, Pyongyang, D. P. R. Korea
}

Received 8 June 2005, Accepted 6 July 2005

\begin{abstract}
Subtilisin QK, which is newly identified as a fibrinolytic enzyme from Bacillus subtilis QK02, has the ability of preventing nitrotyrosine formation in bovine serum albumin induced by nitrite, hydrogen peroxide and hemoglobin in vitro verified by ELISA, Western-blot and spectrophotometer assay. Subtilisin QK also attenuates the fluorescence emission spectra of bovine serum albumin in the course of oxidation caused by nitrite, hydrogen peroxide and hemoglobin. Furthermore, subtilisin QK could suppress the transformation of oxy-hemoglobin to met-hemoglobin caused by sodium nitrite, but not the heat-treated subtilisn QK. Compared with some other fibrinolytic enzymes and inactivated subtilisin QK treated by phenylmethylsulfonylfluoride, the ability of inhibiting met-hemoglobin formation of subtilisin QK reveals that the anti-oxidative ability of subtilisin QK is not concerned with its fibrinolytic function. Additionally, nitrotyrosine formation in proteins from brain, heart, liver, kidney, and muscle of mice that is intramuscular injected the mixture of nitrite, hydrogen peroxide and hemoglobin is attenuated by subtilisin QK. Subtilisin QK can also protect Human umbilical vein endothelial cell ( $E C V-304)$ from the damage caused by nitrite and hydrogen peroxide.
\end{abstract}

Keywords: Fibrinolysis, Hemoglobin, Hydrogen peroxide, Nitrotyrosine, Protein nitration

"Juho Ko and Junpeng Yan contributed equally to this work.

*To whom correspondence should be addressed.

Tel: 86-27-68752938; Fax: 86-27-68761431

E-mail:qiyipeng@whu.edu.cn; qypkjh@yahoo.com.cn

\section{Introduction}

Microorganisms are important sources of thrombolytic agents, because they have some advantages in large quantity of production and oral administration for thrombotic diseases such as the acute myocardial and cerebral infarctions.

Subtilisin QK, produced by Bacillus subtilis QK02 that screened form the fermented soybean by fibrin plate method, has comparatively high fibrinolytic activity on both heated plasma and fibrin plate and is highly homologous to nattokinase (NK) (Ko et al., 2004). NK (or designated subtilisin NAT), a serine protease produced from Bacillus natto (Sumi et al., 1987; Fujita et al., 1993), has approximately four-time stronger fibrinolytic activity than plasmin in clot lysis assay, in vivo (Fujita et al., 1995b). The oral administration of NK produced a mild and frequent enhancement of the fibrinolytic activity in plasma, as indicated by the fibrinolytic parameters and the production of tissue plasminogen activator ( $\mathrm{t}-\mathrm{PA}$ ), which suggests NK represents a possible drug applied not only in the treatment but also in the prevention of thrombotic diseases (Sumi et al., 1990). Then it is confirmed that NK is absorbed from the rat intestinal tract and cleaves fibrin in plasma after intra-duodenal administration of the enzyme (Fujita et al., 1995b). Besides its direct effect to dissolve thrombus, the potentiated fibrinolysis of NK depends on its ability to inactivate plasminogen activator inhibitor 1 (PAI-1) by limited proteolysis of its reactive site (Urano et al., 2001). Moreover, it was reported that NK showed enhanced thrombolytic activity near the vessel wall (Suzuki et al., 2003a) and suppress intimal thickening after vascular injury (Suzuki et al., 2003b).

Reperfusion through thrombolysis by using thrombolytic agents is a standard way to treat impending acute myocardial infarction, but reperfusion itself may lead to accelerated and additional myocardial injury through the oxidative stress. This is referred to as the "reperfusion injury". Since reperfusion injury is initiated by the treatment of myocardial infarction, it is of importance to limit the extent of the injury (Wang et al., 
2002). The cardiovascular disease was associated with progressive changes in the production of free radicals and radical-derived reactive species. These intermediates react with all major cellular constituents and may serve several physiological and pathophysiological functions (Turko et al., 2002). Vascular endothelial cells are crucial both to the integrity of the vessel wall and to modulation of vascular resistance by releasing nitric oxide (NO). However, they are subject to the deleterious effects of oxidant stress originating in bloodstream, underlying tissues, and oxidants generated within the cells (James et al., 2003).

Protein tyrosine nitration produced by the reaction of nitrogen and oxygen species was used as a suitable marker of radical mediated tissue damage (Fisarkova, 2002; Schopfer et al.,2003). Incubation of human hemoglobin ( $\mathrm{Hb})$ with nitrite and hydrogen peroxide was found to induce auto-nitration and nitration of another protein (Grzelak et al., 2001).

Based on these considerations, we have researched the relationship between subtilisin QK, a new fibrinolytic enzyme, and some proteins (BSA and $\mathrm{Hb}$, in vitro and tissues proteins, in vivo) under the oxidative stress condition.

\section{Marerial and Methods}

Materials BSA, sodium nitrite $\left(\mathrm{NaNO}_{2}\right)$ and hydrogen peroxide $\left(\mathrm{H}_{2} \mathrm{O}_{2}\right)$ were purchased from Roche Co.. All solvents and other reagents were the highest purity and commercially available. Antinitrotyrosine monoclonal antibody (mouse) and goat anti-mouse IgG-Ap antibody were purchased from CAYMAN CHEMICAL $\mathrm{Co} . \mathrm{Hb}$, benzamidine, aprotinin, leupeptin, pepstatin A and PMSF were purchased from Sigma Co. Human umbilical vein endothelial cell (ECV-304 cell line) was purchased from CCTCC (Number GDC-023) in China. The solution of subtilisin QK $(0.2 \mathrm{mg} / \mathrm{mL}$, in $50 \mathrm{mM}$ sodium phosphate buffer, $\mathrm{pH}$ 7.0) was prepared from the lyophilized powder of subtilisin QK $(41,000 \mathrm{IU} / \mathrm{mg})$ purified from Bacillus subtilis QK02 (Ko et al., 2004).

ELISA and Western-blot assay ELISA, spectrophotometer, and Western-blot (Bian et al., 2003) were all used for the determination of nitrotyrosine formation in BSA oxidized by nitrite, hydrogen peroxide, and $\mathrm{Hb}$ in the absence or at the presence of subtilisin $\mathrm{QK}$. Western-blot was done as follows: BSA $(2 \mathrm{mg} / \mathrm{ml})$ in $0.1 \mathrm{M}$ phosphate buffer ( $\mathrm{pH} 7.4)$ was incubated at $37^{\circ} \mathrm{C}$ with $\mathrm{Hb}(25 \mu \mathrm{M})$, $\mathrm{NaNO}_{2}(1 \mathrm{mM}), \mathrm{H}_{2} \mathrm{O}_{2}(1 \mathrm{mM})$ and subtilisin QK $(0,5,20,40 \mu \mathrm{g})$ for $30 \mathrm{~min}$. $50 \mu \mathrm{L}$ reaction aliquots was mixed with $50 \mu \mathrm{L}$ sample loading buffer. Equal amounts of proteins were loaded into the gel for each experimental sample. Separated proteins were transferred to PVDF membrane and the membrane was incubated with the anti- nitrotyrosine monoclonal antibody. The nitrated BSA was detected by goat anti-mouse alkaline phosphatase (AP)-conjugated IgG antibody.

Intrinsic fluorescence spectroscopy assay Intrinsic Fluorescence Spectroscopy assay was used to detect structural changes of BSA that was oxidized by nitrite, hydrogen peroxide, and $\mathrm{Hb}$ with or without subtilisin QK. Intrinsic Fluorescence Spectroscopic experiments were carried out at $37^{\circ} \mathrm{C}$ using LS-55 luminescence spectrometer (PerkinElmer Life Sciences, Shelton, CT). BSA solution at a final concentration of $1 \mathrm{mM}$, was incubated with $\mathrm{Hb}(50 \mathrm{mg}), \mathrm{NaNO}_{2}$ $(100 \mathrm{mM}), \mathrm{H}_{2} \mathrm{O}_{2}(100 \mathrm{mM})$, in the absence or at the presence of subtilisin QK (1 or $2 \mathrm{mg}$ ) for 30 minutes at $37^{\circ} \mathrm{C}$. In the measurement of fluorescence quenching, the protein solution was excited at 280 $\mathrm{nm}$, and the emission spectra were recorded from 300 to $420 \mathrm{~nm}$. The excitation and emission slits were $10 \mathrm{~nm}$ and $6 \mathrm{~nm}$, respectively, and the scan speed was $100 \mathrm{~nm} / \mathrm{min}$.

Spectrophotometer assay Oxy-hemoglobin solution was prepared from fresh blood of mice (body weight, 25-30 g) as previously described (Ana et al., 1998). Optical absorption spectra were recorded in a dual-wavelength, double-beam spectrophotometer (UV-2401PC, SHIMADZU Co., Tokyo, Japan). The optical absorption spectra of oxy-hemoglobin solution from the mouse demonstrate the specific wavelengths at 415,541 and $577 \mathrm{~nm}$ (data not shown). The $20 \mu \mathrm{L}$ of $50 \mathrm{mM}$ sodium nitrite $(50 \mathrm{mM}$ sodium phosphate buffer, $\mathrm{pH}$ 7.0) solution and $200 \mu \mathrm{L}$ of $\mathrm{Hb}$ solution were poured into an absorption vessel with $2 \mathrm{~mL}$ of $50 \mathrm{mM}$ sodium phosphate buffer ( $\mathrm{pH}$ 7.0), intimately mixed and record every 2 minutes until the completion of the reaction. The spectral time course for oxyhemoglobin solution with $\mathrm{NaNO}_{2}$ exhibited that the spectra were decreased in the absorption at $1=541$ and $577 \mathrm{~nm}$ and increased at $1=630 \mathrm{~nm}$ (data not shown). These variations in the absorption at $1=541,577$ and $630 \mathrm{~nm}$ indicates the existence of met-hemoglobin (Abdu et al., 1998; Privalle et al., 2000).

Animal test Male mice (body weight, 25-30 g) were obtained from Wuhan University animal center. Mice were divided into three groups (every group contains ten mice); the normal group was not injected, the oxidation group was intramuscular injected with 0.5 $\mathrm{ml}$ of solution I $\left(\mathrm{NaNO}_{2} ; 5 \mathrm{mM}, \mathrm{H}_{2} \mathrm{O}_{2} ; 5 \mathrm{mM}, \mathrm{Hb} ; 25 \mu \mathrm{M}\right)$, and the treatment group was injected with solution I containing subtilisin QK (40 $\mu \mathrm{g}, 1600 \mathrm{IU})$. Injection was performed three times at intervals of two hours. 2 hours after the last injection, each group of mice was killed and the brain, heart, lung, liver, kidney, spleen and skeletal muscle between the ribs were quickly isolated, the tissues were frozen in liquid nitrogen immediately for further analysis. Frozen tissues were pulverized with a pestle and mortar that contained liquid nitrogen. For protein extraction, these tissues were homogenized at $4^{\circ} \mathrm{C}$ in $20 \mathrm{mM}$ Tris- $\mathrm{HCl}$ buffer $(\mathrm{pH}$ 7.4) containing protease inhibitors (final concentration: $1 \mathrm{mM}$ benzamidine, 0.01 KU aprotinin, $10 \mu \mathrm{g} / \mathrm{ml}$ leupeptin, $10 \mu \mathrm{g} / \mathrm{ml}$ pepstatin A, $0.2 \mathrm{mM}$ PMSF). Each sample was homogenized and sonicated on ice. The homogenates were centrifuged at $10,000 \times g$ for $15 \mathrm{~min}$ at $4^{\circ} \mathrm{C}$, and the supernatant was used for detection of nitrotyrosine. Nitrotyrosine was detected by ELISA and Western-blot using anti-nitrotyrosine monoclonal antibody (Bian et al., 2003).

Cellular assay ECV-304 cells were cultured in RPMI-1640 medium (GIBCO/BRL) containing 10\% (v/v) fetal bovine serum (FBS) and double antibiotics in 24-well plates. When the cells reached confluence (about $8 \times 10^{5}$ cells/well) on the plastic plate, the cells were washed three times with FBS-free RPMI-1640 and subjected to oxidation test. Cell injury was initiated by addition of growth culture containing $\mathrm{NaNO}_{2}$ and $\mathrm{H}_{2} \mathrm{O}_{2}(0.5 \mathrm{mM}$, respectively) into each well, with or without subtilisin QK $(5 \mu \mathrm{g}, 200 \mathrm{IU}$ or 10 
$\mu \mathrm{g}, 400 \mathrm{IU})$. After $24 \mathrm{~h}$, cells were inspected and calculated. Cell viability was determined by using colorimetric MTT assay (Claise et al., 1999). Experiment was repeated three times and values were averaged.

Statistical analysis Data are expressed as mean \pm SEM. Results were analyzed by using one-way ANOVA, and statistical significance assumed when $P$ values were $<0.05$.

\section{Results}

Subtilisin QK inhibits tyrosine nitration in BSA To test whether subtilisin QK has an effect on BSA tyrosine nitration, BSA was incubated with different concentrations of subtilisin QK in $\mathrm{Hb} / \mathrm{NO}_{2}^{-} / \mathrm{H}_{2} \mathrm{O}_{2}$ system. As shown Fig. 1, nitrotyrosine level in BSA was significantly decreased due to addition of subtilisin QK. When $40 \mu \mathrm{g}$ of subtilisin QK was added into the reaction mixture, the absorption of the reaction mixture at $630 \mathrm{~nm}$ was close to the background hemoglobin absorption in ELISA assay (Fig. 1A) and complete inhibition of tyrosine nitration in BSA was exhibited in Western-blot assay (Fig. 1B). Similar results were also obtained in spectrophotometer assay (data not shown).

Fluorescence emission spectra of tyrosine and tryptophan residues in BSA The basic information contained in fluorescence measurements relates to the molecular environment of the chromophore. Fluorescence of tryptophan residues is very sensitive to the changes in their vicinity, thus it is widely used to study variations of the molecular conformations of proteins. BSA contains two tryptophan residues, one can evaluate the interactions between protein and dendrimer molecules by studying changes of fluorescence spectra (Gelamo et al., 2002). The wavelength of the fluorescence maximum for BSA was at $348 \mathrm{~nm}$, which indicated that the tryptophan residue (Trp134) is in contact with bound water molecules. Commonly used method to study the environment of tryptophans is to measure the shift in the wavelength of emission maximum. The shift in the position of emission maximum corresponds to the changes of the polarity around chromophore molecule. The red shift indicates that tryptophans are, on average, more exposed to the solvent, whereas the blue shift is a consequence of transferring tryptophan residues into a more hydrophobic environment (Klajnert et al., 2003).

To further examine the role of subtilisin $\mathrm{QK}$ in inhibiting BSA oxidation by $\mathrm{Hb}, \mathrm{NaNO}_{2}$ and $\mathrm{H}_{2} \mathrm{O}_{2}$, we observed the fluorescence emission spectra of tyrosine and tryptophan residues in BSA. Illumination with $280 \mathrm{~nm}$ light excites both of tyrosine and tryptophan residues (Fan et al., 1999; Evgenia et al., 2001). When excited at this wavelength, BSA exhibits a strong fluorescence emission peak at $345 \mathrm{~nm}$ and the interaction of oxidants with BSA quenches this fluorescence emission peak, causing about $65.4 \%$ decrease in the intensity, but the addition of subtilisin QK (2 mg) significantly decreased

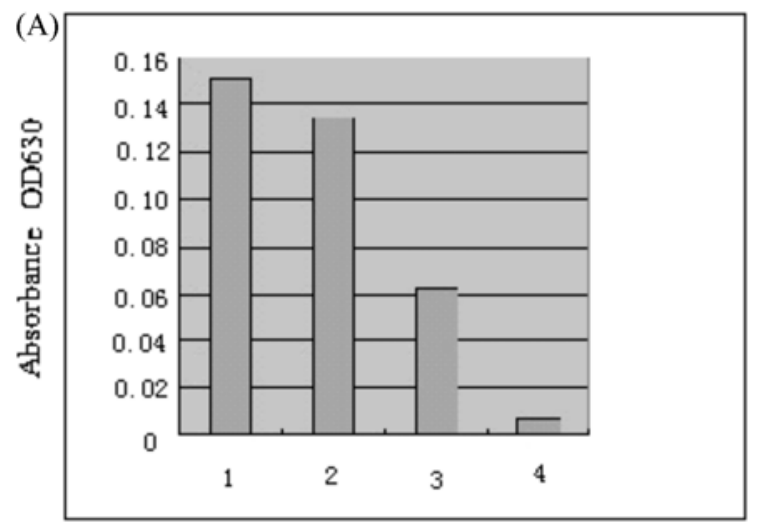

(B)

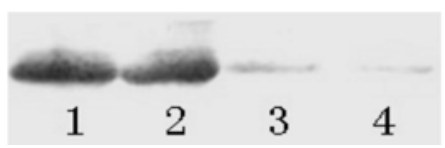

Fig. 1. Effect of subtilisin $\mathrm{QK}$ on the BSA tyrosine nitration in $\mathrm{Hb} / \mathrm{NO}_{2}-/ \mathrm{H}_{2} \mathrm{O}_{2}$ system. (A) ELISA analysis (B) Westhern blot assay; 1: control (without subtilisin $\mathrm{QK}$ ); 2: addition of $5 \mu \mathrm{g}$ subtilisin QK; 3: addition of $20 \mu \mathrm{g}$ subtilisin QK; 4: addition of $40 \mu \mathrm{g}$ subtilisin QK; BSA $(2 \mathrm{mg} / \mathrm{ml})$ in $0.1 \mathrm{M}$ phosphate buffer (pH 7.4) was incubated with $\mathrm{Hb}(25 \mu \mathrm{M}), \mathrm{NaNO}_{2}(1 \mathrm{mM})$, and $\mathrm{H}_{2} \mathrm{O}_{2}(1 \mathrm{mM})$ under the condition of addition of subtilisin QK $(0$, $5,20,40 \mu \mathrm{g})$ for $30 \mathrm{~min}$ at $37^{\circ} \mathrm{C}$. In Fig. 1A, hemoglobin absorbance background was abstracted.

the conformational changes of BSA caused by the oxidants, as shown by a little change in the fluorescence emission intensity (22.8\%) (Fig. 2A). The slight blue shift of emission maximum $(3 \mathrm{~nm})$ was observed in the oxidized BSA (Fig. 2A). As the blue shift is a consequence of transferring tryptophan residues into a more hydrophobic environment, we measured the illumination at $295 \mathrm{~nm}$ light, which excites tryptophan residues. When excited at this wavelength, the intensity quenching (by about 51.7\%) was obtained, which is largely decreased by subtilisin QK (16.2\%) (Fig. 2B).

These results revealed that the interaction of oxidants with BSA altered the microenvironment around tryptophan and tyrosine residues of the protein, but subtilisin QK could protect BSA from the structural alteration induced by oxidative stress.

Subtilisin QK prevent the Met-hemoglobin formation To further evaluate the effect of subtilisin $\mathrm{QK}$ on the protein nitration, we have compared it with hemoglobin and other proteins. Oxy-hemoglobin was oxidized to met-hemoglobin by nitrite and appearance of met-hemoglobin represented as the decrease in absorbance at $577 \mathrm{~nm}$ (Fig. 3. line 7) and the increase at $630 \mathrm{~nm}$ and $406 \mathrm{~nm}$ (Depto et al., 1998). Subtilisin QK significantly attenuated the decrease in absorbance at 577 $\mathrm{nm}$ (Fig. 3. line 2, 3) and the increase at $630 \mathrm{~nm}$ and $406 \mathrm{~nm}$ (data not shown). In order to further investigate the nature of this function of subtilisin $\mathrm{QK}$, some enzymes and inactivated form of subtilisin QK were tested here. As demonstrate in Fig. 3, plasmin (fibrinolytic enzyme), urokinase (fibrinolytic enzyme), 

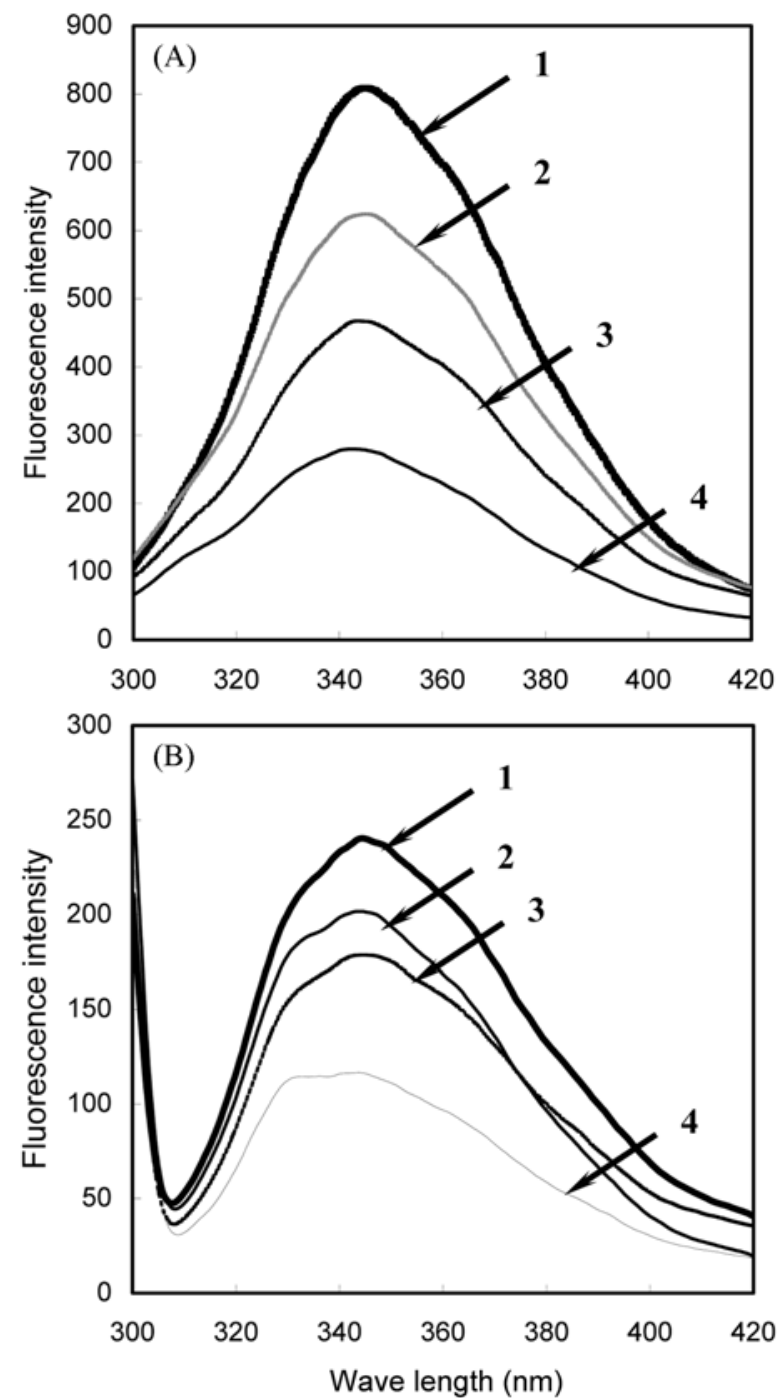

Fig. 2. Fluorescence emission spectra of BSA excited at $280 \mathrm{~nm}$ (A) and $295 \mathrm{~nm}$ (B) in the course of oxidation by $\mathrm{Hb}$, $\mathrm{NaNO}_{2}$, and $\mathrm{H}_{2} \mathrm{O}_{2}$, in absence or presence of subtilisinQK. 1; BSA, 2; BSA + oxidants + subtilisin QK (2 mg), 3; BSA + oxidants + subtilisin QK (1 mg), 4; BSA + oxidants: BSA oxidation was performed by addition of $\mathrm{Hb}(50 \mathrm{mg}), \mathrm{NaNO}_{2}$ $(100 \mathrm{mM})$, and $\mathrm{H}_{2} \mathrm{O}_{2}(100 \mathrm{mM})$ for $25 \mathrm{~min}$ at $37^{\circ} \mathrm{C}$. $\lambda_{\mathrm{EXC}}=$ $280 \mathrm{~nm}$. $E_{X}$ slit $=10 \mathrm{~nm} . E_{\mathrm{m}}$ slit $=6 \mathrm{~nm}$. Scan speed $=100 \mathrm{~nm}$ $\min ^{-1}$. Emission spectrum $=300-420 \mathrm{~nm}$.

thrombin (coagulatic enzyme, serine protease), and trypsin (serine protease) could not inhibit met-hemoglobin formation. PMSF could completely inhibit the fibrinolytic activity of subtilisin QK (Ko et al., 2004), but could not inhibit the antioxidant activity of subtilisin QK for oxy-hemoglobin (Table 1). In addition, heat-treating could completely inhibit both fibrinolytic (Ko et al., 2004) and the anti-oxidant activity of subtilisin QK (Table 1).

These results revealed that anti-oxidant function of subtilisin QK was not concerned with its fibrinolytic activity, and might implicate in its secondary structure.

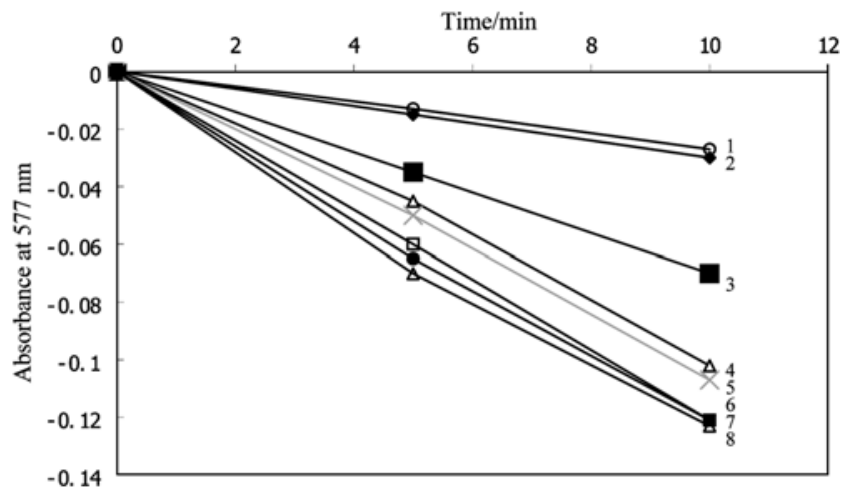

Fig. 3. The anti-oxidant properties of subtilisin $\mathrm{QK}$ on $\mathrm{HbO}_{2}$ at $\mathrm{HbO}_{2} / \mathrm{NaNO}_{2}$ system $(\mathrm{l}=577 \mathrm{~nm})$. 1: oxy-hemoglobin, 2: oxyhemoglobin $+\mathrm{NO}_{2}^{-}+$subtilisin QK (1600IU, $\left.40 \mu \mathrm{g}\right)$, 3: oxyhemoglobin $+\mathrm{NO}_{2}^{-}+$subtilisin $\mathrm{QK}(800 \mathrm{IU}, 20 \mu \mathrm{g})$, 4: oxyhemoglobin $+\mathrm{NO}_{2}^{-}+$thrombin $(10 \mathrm{NIH})$, 5: oxy-hemoglobin + $\mathrm{NO}_{2}^{-}+$trypsin $(40 \mu \mathrm{g}), 6$ : oxy-hemoglobin $+\mathrm{NO}_{2}^{-}+$plasminogen $(1.3 \mathrm{U})+$ urokinase $(1600 \mathrm{IU}), 7$ : oxy-hemoglobin $+\mathrm{NO}_{2}^{-}$(control), 8: oxy-hemoglobin $+\mathrm{NO}_{2}^{-}+$urokinase $(1600 \mathrm{IU})$. All experiments were performed in the total volume $2.2 \mathrm{~mL}$ containing of $\mathrm{NaNO}_{2}$ $\left(4.5 \times 10^{-4} \mathrm{M}\right)$, oxy-hemoglobin $\left(6.8 \times 10^{-5} \mathrm{M}\right)$ and phosphate buffer $(0.05 \mathrm{M}, \mathrm{pH} 7.0)$. The similar results were obtained at $\mathrm{l}=$ 541 and $630 \mathrm{~nm}$ (data not shown).

Effect of subtilisin QK on the protein nitration in some tissues of mouse, in vivo In order to investigate the effect of subtilisin $\mathrm{QK}$ on the protein nitration, in vivo, we injected $\mathrm{Hb}$, $\mathrm{NaNO}_{2}$ and $\mathrm{H}_{2} \mathrm{O}_{2}$ with or without QK into crus muscle of mice three times at intervals of two hours, two hours after injection, each group of mice was killed and samples of some tissues was prepared as described in materials and methods. The detection of nitrotyrosine formation in samples by ELISA using nitrotyrosine monoclonal antibody (Fig. 4) revealed that subtilisin QK could significantly inhibit nitrotyrosine formation in brain, heart, liver, kidney and muscle tissues, but not in lung and spleen.

Mice were divided into three groups of normal, oxidation and treatment groups as described in the part of Methods. QK (1600 IU, $40 \mu \mathrm{g}$ ) effectively prevented the protein nitration in brain, heart, liver, kidney, and muscle. The values are averages of ten samples in every group. This indicated that subtilisin QK could prevent the protein nitration induced by $\mathrm{Hb}, \mathrm{NaNO}_{2}$ and $\mathrm{H}_{2} \mathrm{O}_{2}$, in vivo.

The effect of subtilisin QK on the human umbilical vein endothelial cell (ECV-304 cell line) damaged by $\mathrm{NaNO}_{2}$ and $\mathbf{H}_{2} \mathbf{O}_{2}$ We investigated whether subtilisin QK could protect endothelial cell from the cytotoxicity of exogenous oxidants. ECV-304 cell line, which was isolated from human umbilical vein at 1996, has several advantages over HUVEC (Sian 1996). Our experiment revealed that subtilisin QK could prevent ECV-304 cells from cell death caused by exogenous nitrite and hydrogen peroxide (Fig. 5). To quantitatively evaluate the protection effect of subtilisin QK, the cell 
Table 1. Effect of PMSF and heat-treating on the inhibition of subtilisin QK against the met-hemoglobin formation by nitrite

\begin{tabular}{ccccc}
\hline Test group & Subtilisn QK & PMSF & $\Delta$ OD $_{630 \mathrm{~nm}}$ & Inhibition (\%) \\
\hline 1 & + & + & $0.025 \pm 0.001$ & 70.9 \\
2 & - & + & $0.064 \pm 0.003$ & 25.5 \\
3 & + & - & $0.028 \pm 0.003$ & 67.4 \\
4 & + (Heated) & - & $0.082 \pm 0.005$ & 4.6 \\
5 (control) & - & - & $0.086 \pm 0.001$ & 0 \\
\hline
\end{tabular}

Table 2. The effect of subtilisin QK on ECV-304 cell viability

\begin{tabular}{cccccr}
\hline Test group & Growth medium & $\mathrm{NaNO}_{2}+\mathrm{H}_{2} \mathrm{O}_{2}(\mathrm{mM})$ & $\begin{array}{c}\text { Subtilisin } \\
\text { QK (IU) }\end{array}$ & $\begin{array}{c}\text { Living Cells } \\
\left(\times 10^{5} \text { cells }\right)\end{array}$ & $\begin{array}{c}\text { Viability } \\
(\%)\end{array}$ \\
\hline 1 & + & 0 & 0 & $7.9 \pm 0.2$ & 100.0 \\
2 & + & 0.5 & 0 & $0.64 \pm 0.08$ & 8.2 \\
3 & + & 0.5 & 200 & $6.4 \pm 0.3$ & 81.0 \\
4 & + & 0.5 & 400 & $7.9 \pm 0.3$ & 100.0 \\
\hline
\end{tabular}

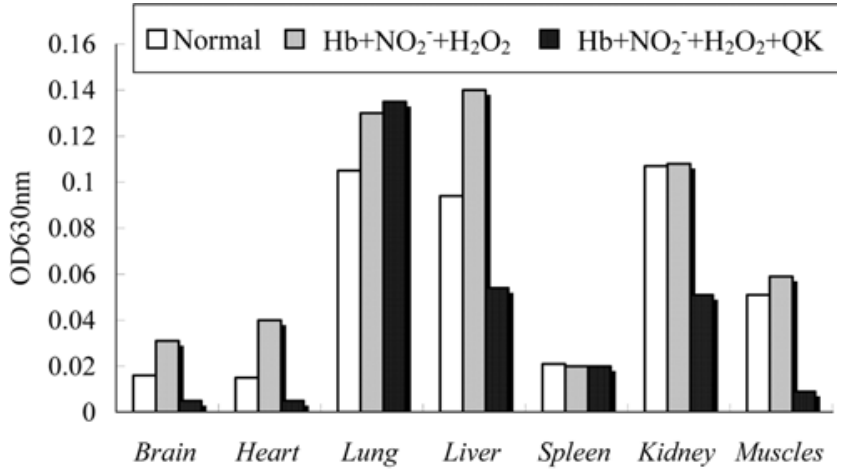

Fig. 4. ELISA for nitrotyrosine in tissue homogenates from brain, heart, lung, liver, kidney, spleen and muscle of mice subjected to oxidation stress.

viability was investigated by using MTT method, and subtilisin QK completely inhibited ECV-304 cell death caused by the exogenous nitrite and hydrogen peroxide when $10 \mu \mathrm{g}$ protein (400 IU) was added (Table 2).

These results indicate that subtilisin QK in blood could not only dissolve thrombus, but also protect BSA, free hemoglobin and the endothelial cells from cytotoxicity of $\mathrm{NO}_{2}^{-}$and $\mathrm{H}_{2} \mathrm{O}_{2}$.

\section{Discussion}

It is well known that intravenous administration of urokinase, streptokinase and tissue plasminogen activator has been widely used for thrombosis therapy, but these agents have some disadvantages such as bleeding and high cost. But the fibrinolytic enzymes from microorganism living in the healthy food had many advantages: oral administration, long half-life in plasma, high affinity to fibrin, increasing tissue plasminogen activator, inactivating PAI-1, and so on (Sumi et al., 1987; Fujita et al., 1993; Fujita et al., 1995a; Fujita et al., 1995b; Urano et al., 2001; Suzuki et al., 2003a; Suzuki et al., 2003b;
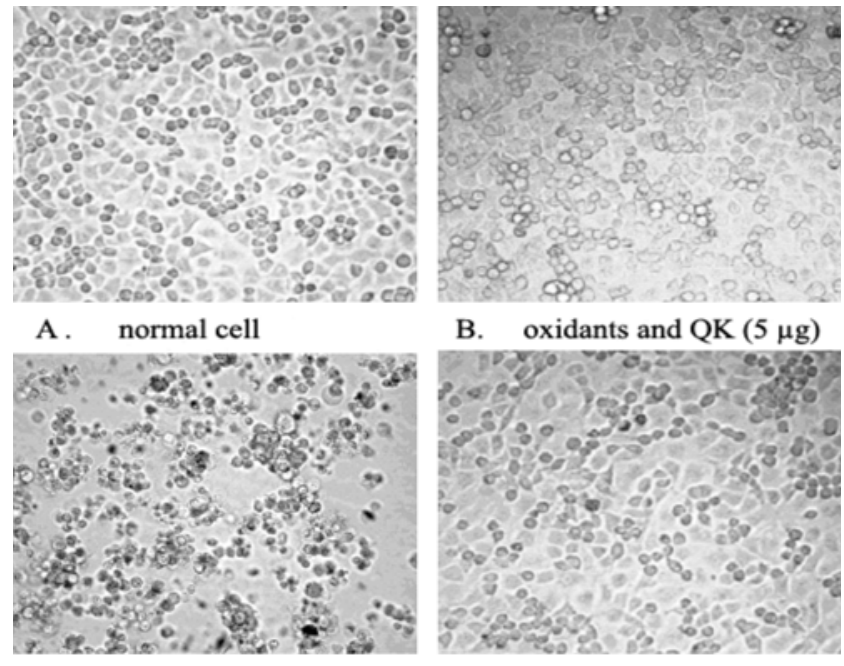

C.

$$
\text { oxidants }
$$

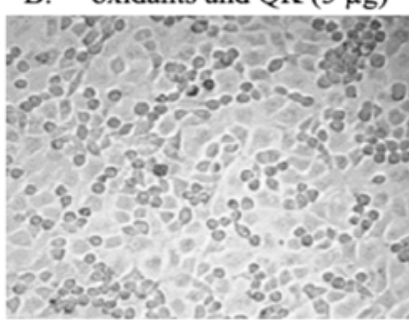

D. oxidants and QK $(10 \mu \mathrm{g})$

Fig. 5. The protection effect of $\mathrm{QK}$ on human umbilical vein endothelial cells (ECV-304) from oxidant stress. A: control (growth medium), B: $\mathrm{NaNO}_{2}(0.5 \mathrm{mM})+\mathrm{H}_{2} \mathrm{O}_{2}(0.5 \mathrm{mM})+$ subtilisn QK $(200 \mathrm{IU}, 5 \mu \mathrm{g}), \mathrm{C}: \mathrm{NaNO}_{2}(0.5 \mathrm{mM})+\mathrm{H}_{2} \mathrm{O}_{2}(0.5 \mathrm{mM}), \mathrm{D}$ : $\mathrm{NaNO}_{2}(0.5 \mathrm{mM})+\mathrm{H}_{2} \mathrm{O}_{2}(0.5 \mathrm{mM})+$ subtilisn QK (400 IU, 10 $\mu \mathrm{g})$. At $24 \mathrm{~h}$ after the addition of oxidant and subtilisin QK into growth medium, cells were taken photography. We can see in Fig. 5, the cells in panel A are all sticked to the cell culture plate and grow homogeneously, but all the cell in panel $\mathrm{C}$ floated and collected under the oxidative stress. Panel B and C indicate cells are protected by QK from oxidant stress.

Ko et al.2004). Subtilisin QK was newly isolated and identified from the culture broth of Bacillus subtilis QKO2 which has the highest fibrinolytic activity among the strains screened from the fermented soybean, and its fibrinolytic activity was $41.000 \mathrm{IU} / \mathrm{mg}$ (Ko et al., 2004).

In order to develop it as a pharmacological agent, we have researched its function in blood and found that it could inhibit the nitration of BSA and oxy-hemoglobin. Serum albumin is 
one of the most available and extensively studied proteins. It is the major component of blood plasma in many species, accounting for about $60 \%$ of its total protein content and providing about $80 \%$ of the blood osmotic pressure. It is the carrier of many low-polar metabolites and drugs in the blood (Ercelena et al., 2003). In the presence of hydrogen peroxide, hemoglobin oxidized nitrite, which resulted in BSA nitration. BSA nitration results in conformational and functional alteration (Bian et al., 2003).

Subtilisin QK could inhibit nitrotyrosine formation and conformational changes in BSA caused by hemoglobin, nitrite and hydrogen peroxide (Fig. 1, 2). Here, hemoglobin acts as a nitrite reductase to produce nitric oxide (NO) from nitrite, a major bio-available pool of $\mathrm{NO}$, and itself was oxidized to met-hemoglobin (Bian et al., 2003; Cosby et al., 2003). Numerous pathologies may involve toxic side effects of methemoglobin-derived free heme and heme derived iron. In support, hemoglobin in plasma, when oxidized to methemoglobin by oxidants, causes oxidative modification of LDL, which in turn induces endothelial cytolysis primarily caused by lipid hydroperoxides (Balla et al., 2000; Jeney et al., 2002).

As demonstrated in Fig. 3 and Table 1, subtilisin QK significantly inhibited the met-hemoglobin formation induced by nitrite, it did not concerned with its fibrinolytic function. From these results, we assumed that subtilisin QK could prevent proteins in tissues and cells, especially heme containing protein rich tissues and vascular endothelial cells, from exogenous oxidative stress. Heme containing proteins such as hemoglobin and myoglobin are widely distributed in body, especially heart, liver and muscles (Bian et al., 2003). Vascular endothelial cells are also highly vulnerable to oxidative injury, because they are in close contact with leukocytes generated ROS and its endogenous NO (Shimpuku et al., 2000; James et al., 2003).

Nitration of tyrosine in biological conditions represents a pathological event that is associated with several neurodegenerative diseases, such as amyotrophic lateral sclerosis, Parkinson's disease and Alzheimer's disease (AD). Increased level of nitrated proteins have been reported in $\mathrm{AD}$ brain (Castegna et al., 2003). Our results showed that subtilisin QK could significantly inhibit nitrotyrosine formation in brain, heart, liver, kidney, and muscle in vivo.

The lumen of blood vessels is covered with a single layer of vascular endothelial cells, which are always in direct contact with the constituents of blood and serve as a barrier enabling selective permeability of substances. Activated leukocytes release the reactive oxygen species (ROS) for biophylaxis. Vascular endothelial cells are highly vulnerable to oxidative injury, because they are in close contact with leukocytes (Shimpuku et al., 2000). And these ROS can react with NO generated by endothelial cells to form peroxynitrite, which is highly reactive and harmful to cell proteins, lipids, and nucleic acids (James et al., 2003). But our results indicated that subtilisin QK could protect ECV-304 cells from exogenous oxidation stress (Fig. 4, 5 and Table 2).

Although it is still unclear how subtilisin QK inhibits protein nitration and exerts its protective function in endothelial cells and rat tissues, these results implicate the fibrinolytic enzymes from Bacillus such as subtilisin QK and NK could reduce the oxidative stress caused damage besides their fibrinolytic activity.

Acknowledgments We thanks prof. Qu Sanfu (CCTCC, Wuhhan University) for his assistance in culture some cell lines and prof. Liang Yi (Institute of Biomolecular structure, College of Life Science, Wuhan University for his help in the fluorescence spectra measurement. Hubei provincial key laboratory of biotechnology of traditonal chinese medicine (Hubei University, Wuhan, Hubei, P.R.China 430062) supported this work.

\section{References}

Abdu, I. A., Beth, A. B. and Robert, E. C. (1998) Peroxynitritemediated heme oxidation and protein modification of native and chemically modified hemoglobins. Arch. Biochem. Biophys. 349, 65-73.

Ana, D., José, M. S. and Rafael, R. (1998) Diffusion of peroxynitrite across erythrocyte membranes. Proc. Natl. Acad. Sci. USA 95, 3566-3571.

Balla, J., Balla, G., Jeney, V., Kakuk, G., Jacob, H. S. and Vercellotti, G. M. (2000) Ferriporphyrins and endothelium: a 2edged sword-promotion of oxidation and induction of cytoprotectants. Blood 95, 3442-3450.

Bian, K., Gao, Z., Weisbrodt, N. and Murad, F. (2003) The nature of heme/iron-induced protein tyrosine nitration. Proc. Natl. Acad. Sci. USA 100, 5712-5717.

Castegna, A., Thongboonkerd, V., Klein, J. B., Lynn, B., Markesbery, W. R. and Butterfield, D. A. (2003) Proteomic identification of nitrated proteins in Alzheimer's disease brain. J. Neurochem. 85, 1394-1401.

Claise, C., Edeas, M., Chaouchi, N., Chalas, J., Capel, L., Kalimouttou, S., Vazquez, A. and Lindenbaum, A. (1999) Oxidized-LDL induce apoptosis in HUVEC but not in the endothelial cell line EA.hy 926. Atherosclerosis 147, 95-104.

Cosby, K., Partovi, K. S., Crawford, J. H., Patel, R. P., Reiter, C. D., Martyr, S., Yang, B. K., Waclawiw, M. A., Zalos, G., Xu, X., Huang, K. T., Shields, H., Kim-Shapiro, D. B., Schechter, A. N., CannonIII, R. O. and Gladwin, M. T. (2003) Nitrite reduction to nitric oxide by deoxyhemoglobin vasodilates the human circulation. Nat. Med. 9, 1498-1505.

Depto, Q., Facultad, Q., Universidad, S. C. and Santiago, C. (1998) Autocatalytical oxidation of hemoglobin by nitrite: a possible mechanism. Free. Rad. Biol. Med. 24, 1535-1536.

Ercelena, S., Klymchenko, A. S. and Demchenko, A. P. (2003) Novel two-color fluorescence probe with extreme specifcity to bovine serum albumin. FEBS Lett. 538, 25-28.

Evgenia, L., Artem, N., Alexander, I. S., Oshra, S., Gertz, I. L. and Dan, M. (2001) Effect of albumin on the kinetics of ascorbate oxidation. Biochim. Biophys. Acta. 1526, 53-60.

Fan, Z., Mary, T., David, L. M. and Chen, C. H. (1999) 
Conformational alteration in serum albumin as a carrier for pyridoxal phosphate: a distinction from pyridoxal phosphatedependent glutamate decarboxylase. Arch. Biochem. Biophys. 364, 195-202.

Fisarkova, B. (2002) 3-nitrotyrosine--an indicator of changes in the formation of reactive oxygen and nitrogen species. Cesk. Fysiol. 51, 159-168.

Fujita, M., Nomura, K., Hong, K., Ito, Y., Asada, A. and Nishimuro, S. (1993) Purification and characterization of a strong fibrinolytic enzyme (nattokinase) in the vegetable cheese natto, a popular soybean fermented food in Japan. Biochem. Biophys. Res. Commun. 197, 1340-1347.

Fujita, M., Hong, K., Ito, Y., Misawa, S., Takeuchi, N., Kariya, K. and Nishimuro, S. (1995a) Transport of nattokinase across the rat intestinal tract. Biol. Pharm. Bull. 18, 1194-1196.

Fujita, M., Hong, K., Ito, Y., Fujii, R., Kariya, K. and Nishimuro, S. (1995b) Thrombolytic effect of nattokinase on a chemically induced thrombosis model in rat. Biol. Pharm. Bull. 18, 13871391.

Gelamo, E. L., Silva, C. H. T. P., Imasato, H. and Tabak, M. (2002) Interaction of bovine (BSA) and human (HSA) serum albumins with ionic surfactants: spectroscopy and modeling. Biochim. Biophys. Acta. 1594, 84-99.

Grzelak, A., Balcerczyk, A., Mateja, A. and Bartosz, G. (2001) Hemoglobin can nitrate itself and other proteins. Biochim. Biophys. Acta. 1528, 97-100.

James, M. M., Zhi-chao, Q. and Xia, L. (2003) Ascorbic acid blunts oxidant stress due to menadione in endothelial cells. Arch. Biochem. Biophys. 411, 136-144.

Jeney, V., Balla, J., Yachie, A., Varga, Z, Vercellotti, G. M., Eaton, J. W. and Balla, G. (2002) Pro-oxidant and cytotoxic effects of circulating heme. Blood 100, 879-887.

Klajnert, B., Stanislawska, L., Bryszewska, M. and Palecz, B. (2003) Interactions between PAMAM dendrimers and bovine serum albumin. Biochim. Biophys. Acta. 1648, 115-126.

Ko, J. H., Yan, J. P., Zhu, L. and Qi, Y. P. (2004) Identification of two novel fibrinolytic enzymes from Bacillus subtilis QK02. Comp. Biochem. Physiol. C Toxicol. Pharmacol. 137, 65-74.

Privalle, C., Talarico, T., Keng, T. and Deangelo, J. (2000) Pyridoxalated hemoglobin polyoxyethylene: a nitric oxide scavenger with anti-oxidant activity for the treatment of nitric oxide-induced shock. Free. Rad. Biol. Med. 28, 1507-1517.

Schopfer, F. J., Baker, P. R. and Freeman, B. A. (2003) NOdependent protein nitration: a cell signaling event or an oxidative inflammatory response? Trends Biochem. Sci. 28, 646-654.

Shimpuku, H., Tachi, Y., Shinohara, M. and Ohura, K. (2000) Effect of vitamin $\mathrm{E}$ on the degradation of hydrogen peroxide in cultured human umbilical vein endothelial cells. Life Sci. 68, 353-359.

Sian, E. H. (1996) Functional characterization of the spontaneously transformed human umbilical vein endothelial cell line ECV304: Use in an in vitro model of angiogenesis. Exp. Cell. Res. 225, 171-185.

Sumi, H., Hamada, H., Tsushima, H., Mihara, H. and Muraki, H. (1987) A novel fibrinolytic enzyme (nattokinase) in the vegetable cheese Natto; a typical and popular soybean food in the Japanese diet. Experientia, 43, 1110-1111.

Sumi, H., Hamada, H., Nakanishi, K. and Hiratani, H. (1990) Enhancement of the fibrinolytic activity in plasma by oral administration of nattokinase. Acta Haematol. 84, 139-143.

Suzuki, Y., Kondo, K., Matsumoto, Y., Zhao, B. Q., Otsuguro, K., Maeda, T., Tsukamoto, Y., Urano, T. and Umemura, K. (2003a) Dietary supplementation of fermented soybean, natto, suppresses intimal thickening and modulates the lysis of mural thrombi after endothelial injury in rat femoral artery. Life Sci. 73, 1289-1298

Suzuki, Y., Kondo, K., Ichise, H., Tsukamoto, Y., Urano, T. and Umemura, K. (2003b) Dietary supplementation with fermented soybeans suppresses intimal thickening. Nutrition. 19, 261-264.

Turko, I. V. and Murad, F. (2002) Protein nitration in cardiovascular diseases. Pharmacol. Rev. 54, 619-634.

Urano, T., Ihara, H., Umemura, K., Suzuki, Y., Oike, M., Akita, S., Tsukamoto, Y., Suzuki, I. and Takada, A. (2001) The profibrinolytic enzyme subtilisin NAT purified from Bacillus subtilis Cleaves and inactivates plasminogen activator inhibitor type 1. J. Biol. Chem. 276, 24690-24696.

Wang, Q. D., John, P., Sjoquist, P. O. and Lars, R. (2002) Pharmacological possibilities for protection against myocardial reperfusion injury. Cardiovasc. Res. 55, 25-37. 